\title{
Pathological study of pulmonary toxicity induced by intratracheally instilled Asian sand dust (Kosa): effects of lowered serum zinc level on the toxicity
}

\author{
Akinori Shimada $^{1}$, Kotaro Miyake ${ }^{1}$, Yuri Kenmotsu ${ }^{1}$, Kikumi Ogihara ${ }^{1}$, Yuko Naya ${ }^{1}$, \\ Misaki Naota ${ }^{2}$, Takehito Morita ${ }^{3}$, Kenichiro Inoue ${ }^{4}$, Hirohisa Takano ${ }^{5}$ \\ ${ }^{1}$ Department of Pathology, School of Life and Environmental Science, Azabu University, \\ Sagamihara-shi, Kanagawa, Japan \\ ${ }^{2}$ Department of Nutritional Science and Food Safety, Tokyo University of Agriculture, Setagaya-ku, \\ Tokyo, Japan \\ ${ }^{3}$ Department of Veterinary Pathology, Tottori University, Tottori-shi, Tottori, Japan \\ ${ }^{4}$ School of Nursing, University of Shizuoka, Shizuoka-shi, Shizuoka, Japan \\ ${ }^{5}$ Department of Environmental Engineering, Kyoto University Graduate School of Engineering, \\ Kyoto-shi, Kyoto, Japan
}

\begin{abstract}
Introduction. We have previously reported that Asian sand dust (ASD) induced acute and chronic inflammatory changes in the lung of mice. Zinc $(\mathrm{Zn})$ is reported to influence inflammation and wound healing. The purpose of the study was to assess the effects of lowered serum $\mathrm{Zn}$ levels on the lung toxicity induced by ASD.

Material and methods. Mice that were fed diets containing normal (group 1) or low (group 2) content of $\mathrm{Zn}$ for 8 weeks were intratracheally instilled with $3.0 \mathrm{mg}$ of ASD, followed by sacrifice at 24 hours, 2 weeks, and 1 , 2 and 3 months after instillation. Paraffin sections of lung tissues were stained by hematoxylin and eosin and by immunohistochemistry to detect tumor necrosis factor (TNF) and interleukin (IL)- $1 \beta$ as well as inflammasome (NALP3), autophagy (LC-3) and lysosome (LAMP-1) markers. Selected samples of lung tissue were examined by electron microscopy.

Results. Following histological examination of the lung, similar patterns of inflammatory changes were observed in mice with normal and low serum $\mathrm{Zn}$ concentrations; however, they were more prominent and persistent in mice with low serum $\mathrm{Zn}$ level. These changes were both purulent (acute) and pyogranulomatous (chronic) in nature. In the lung lesions of group 2 mice the changes within the cytoplasmic vacuoles of enlarged ASD-containing macrophages (Mo) were clearly visible. The macrophages expressed TNF and IL- $1 \beta$, and semi-quantitative analysis revealed a larger number of TNF-positive Mo in mice with normal level of serum $\mathrm{Zn}$ and a larger number of IL-1 $\beta$-positive Mo in mice with low level of serum $\mathrm{Zn}$. Decreased positive LC-3 staining and dilated lysosomes containing ASD particles were observed in the cytoplasm of Mo in mice with low serum $\mathrm{Zn}$ concentration.

Conclusions. These findings suggest that low serum zinc concentration may induce the modulation of cytokine expression and lysosomal malfunction by phagocytotic and/or autophagic mechanisms, and may result in interstitial pyogranulomatous inflammation in the lungs of mice treated with ASD. (Folia Histochemica et Cytobiologica 2018, Vol. 56, No. 1, 38-48)
\end{abstract}

Key words: Asian sand lung toxicity; mice; low zinc level; TNF; IL-1; NALP-3; LC-3; LAMP-1; IHC; electron microscopy

Correspondecne address: A. Shimada

Department of Pathology, School of Life and Environmental

Science, Azabu University, Kanagawa, Japan

tel./fax: 0427691932

e-mail: a-shimada@azabu-u.ac.jp 


\section{Introduction}

Asian sand dust (ASD, also known as Kosa aerosol) originates from the arid deserts of Mongolia and China and causes severe air pollution annually within the Asia-Pacific area [1]. Epidemiological studies of ASD in humans have shown that exposure to ambient ASD particles is associated with an increase in pulmonary $[2-6]$ and cardiovascular problems $[2,3,7,8]$. Because of recent environmental changes, such as desertification and global warming, human and animals are at an increased risk of frequent exposure to ASD and the resultant adverse health effects of ASD on the respiratory system.

Previous studies investigating the pulmonary toxicity caused by intratracheally instilled high doses of ASD demonstrated that the mineralogical components of ASD particles, free from chemical and biological pollutants, caused inflammatory changes in lung tissues of mice. The changes were characterized by acute purulent inflammation and ensuing chronic granulomatous inflammation [9-12]. The direct effects of the ASD particles, release of cytokines from macrophages, and oxidative stress generated in the lesions may be involved in the development of lung toxicity [10].

Lung is subjected to a wide range of insults in air. Alveolar macrophages are the primary innate immune phagocytic cells at the air tissue interface responsible for clearance of particulate matters $[13,14]$. Inflammasome, an oligomer of intracellular proteins, is now believed to be the link between innate immune response to dust and lung inflammation; inorganic particulate matters including silica have been reported to trigger inflammasome activation with resultant cytokine production in alveolar macrophages [15-17].

Zinc ( $\mathrm{Zn})$ is essential for health and well-being. It has a structural and functional role in a large number of macromolecules, and is required for over 300 enzymatic reactions in DNA synthesis, cell division, and protein synthesis - all necessary for tissue regeneration and repair [18]. In addition, $\mathrm{Zn}$ is an essential trace element that participates in wound healing, and $\mathrm{Zn}^{2+}$ binding constitutes an important factor for cell membrane repair [19]. Dynamic membrane repair is a fundamental process in maintaining cellular integrity. Defective membrane repair is associated with compromised wound healing, muscular dystrophy, and cardiovascular disease onset [20]. Moreover, zinc has been reported to be important in airway homeostasis [21] and influence inflammation by the production and signaling of numerous inflammatory cytokines, including tumor necrosis factor (TNF) and interleukin (IL)- $1 \beta$ in a variety of cell types [22-25].
A moderate deficiency of $\mathrm{Zn}$ is often observed in elderly patients, even in industrialized countries [26]. Zinc deficiency has been identified as a significant public health problem contributing to 800,000 deaths worldwide annually [27]. The purpose of the current study was to assess the effects of low serum $\mathrm{Zn}$ on the lung toxicity induced by ASD in an animal model.

\section{Materials and methods}

Animals. A total of 80 male ICR mice ( 5 or 6 weeks old) were obtained from CLEA JAPAN Inc. (Tokyo, Japan). Animals were either fed a CE-2 standard diet $(\mathrm{Zn}=35 \mu \mathrm{g} / \mathrm{g}$, protein $25.13 \%$, fat $4.92 \%$, fiber $4.42 \%$, ash $6.86 \%$, nitrogen free extracts $49.84 \%)$ or an A12551 low $\mathrm{Zn} \operatorname{diet}(\mathrm{Zn}<1 \mu \mathrm{g} / \mathrm{g}$, protein $25.13 \%$, fat $4.92 \%$, fiber $4.42 \%$, ash $6.86 \%$, nitrogen free extracts $49.84 \%$ ) purchased from CLEA JAPAN Inc (Tokyo, Japan) for 8 weeks, a time sufficient to establish zinc deficiency. Water was provided ad libitum throughout the experiment. The mice were housed in cages at a temperature of approximately $25^{\circ} \mathrm{C}$ with $55-70 \%$ humidity. All experiments were performed according to the guidelines of The Laboratory Animal Care Committee of Azabu University, Kanagawa, Japan. Body weight changes were recorded weekly to assess the general health of the mice. Plasma zinc concentrations were evaluated before the experiment to confirm that animals achieved a zinc-deficient state. Zinc analysis was carried out by measuring serum zinc concentrations using the Zinc Assay kit (Metallogenics, Chiba, Japan), following the manufacturer's protocol [21]. Absorbance was measured using an Epoch Microplate Spectrophotometer (BioTek, Tokyo, Japan).

Preparation of particle samples. CJ-2 particles, which are simulated ASD particles, were used in this study. The CJ-2 particles were obtained from General Science Corporation (Tokyo, Japan). The particles were collected from surface soil in the southwest part of the Tengger desert in north-central China where dust storms occur frequently [28]. The CJ-2 particles contained $28.0 \% \mathrm{Si}, 5.9 \% \mathrm{Al}, 5.3 \% \mathrm{Ca}, 3.0 \% \mathrm{Fe}$, $1.7 \% \mathrm{~K}$, and $1.6 \% \mathrm{Mg}$, and the mean diameter of the particles was approximately $0.03 \mathrm{~mm} \pm 0.01 \mathrm{~mm}$, according to the manufacturer's data sheet. The CJ-2 particles were hot air sterilized at $300^{\circ} \mathrm{C}$ for 1 hour to remove toxic substances (microbiological substances and chemicals including nitrogen oxide and sulfur oxide) adhering to ASD. The sterilization temperature was determined in accordance with previous studies [9]. It has been reported that neither the chemical composition nor the shape of mineral particles changed, even when heated to $700^{\circ} \mathrm{C}[29]$.

Preparation of ASD suspensions. The sterilized particles were suspended in $0.05 \mathrm{ml}$ of sterilized $0.9 \% \mathrm{NaCl}$ solution for instillation. The suspensions were deflocculated via ul- 
trasonic disintegration for $30 \mathrm{~min}$, resulting in homogeneous fine particles of less than $2.0 \mu \mathrm{m}$ in diameter. A number of particles with a total mass of $3.0 \mathrm{mg}$ were selected to determine dose effects on lung toxicity in mice. The maximum deposition of particles in the lung of a single mouse was calculated using tidal volume and breathing rate [9]. The maximum weekly deposition of suspended particulate matter $\left(0.1 \mathrm{mg} / \mathrm{m}^{3}\right)$, as measured by the Japanese national air quality standard, was approximately $0.03 \mathrm{mg}$. The instillation dose $(3.0 \mathrm{mg})$ in the present study represents 99 times that amount, respectively [10]. Control mice were administered $0.05 \mathrm{ml}$ of sterilized $0.9 \% \mathrm{NaCl}$ solution.

Study protocol. A total of 40 mice with normal levels of serum $\mathrm{Zn}(93.46 \mu \mathrm{g} / \mathrm{dL} \pm 11.39$, mean $\pm \mathrm{SD})$ and 40 mice with low levels of serum $\mathrm{Zn}$ (less than $40 \mu \mathrm{g} / \mathrm{dL} \pm 8.30$ ) were randomly divided into five control $(\mathrm{n}=3$ each) and five exposure ( $\mathrm{n}=5$ each) groups. The mice were anesthetized using an i.p. injection of sodium pentobarbital $(5 \mathrm{mg} / 100 \mathrm{~g}$ body weight) (Wako, Osaka, Japan). The suspensions were agitated immediately prior to intratracheal instillation, and $0.05 \mathrm{ml}$ of the suspension was instilled in each mouse using an intratracheal cannula. Each intratracheal instillation procedure took 3 seconds.

The mice in each of the five groups were euthanized by exsanguination under deep anesthesia induced by i.p. injection of sodium pentobarbital at 24 hours, 2 weeks, and 1,2 , and 3 months after instillation, respectively. Mice with low levels of serum $\mathrm{Zn}$ were fed a low level of $\mathrm{Zn}$ diet during the experiment.

Pathological examination. Three mice from each control group and five mice from each exposure group were used for pathological examination and immunohistochemistry. The lung lobes were separated, and longitudinal sections from each lobe were prepared. Half of these sections were placed into embedding cassettes and fixed by immersion in $10 \%$ neutral-buffered formalin. The other half of the longitudinal sections from each mouse in the groups sacrificed $24 \mathrm{~h}$ after treatment was used for electron microscopy. The formalin-fixed lung tissues were routinely processed and embedded in paraffin for histopathological and immunohistochemical examination. Sections of lung (approximately $3 \mu \mathrm{m}$ thick) were cut and stained with hematoxylin and eosin (H\&E).

Immunohistochemistry: polymer method. Paraffin-embedded sections of the lungs treated with saline or with $3.0 \mathrm{mg}$ of ASD particles were used for the immunohistochemical detection of cytokines (TNF, IL-1 $\beta$ ), an inflammasome component (NALP3), an autophagy marker (LC-3), and a lysosome marker (LAMP-1). For antigen retrieval, the sections were placed in citrate buffer solution ( $\mathrm{pH} \mathrm{5.4)} \mathrm{and}$ microwaved for $20 \mathrm{~min}$. Endogenous peroxidase activity was quenched with $3 \% \mathrm{H}_{2} \mathrm{O}_{2}$ for $30 \mathrm{~min}$ at room temperature (RT). The slides were then blocked using $10 \%$ normal goat serum for $1 \mathrm{~h}$ at RT. Thereafter, the sections were incubated with primary antibodies overnight at $4^{\circ} \mathrm{C}$ (anti-TNF, 1:200 dilution; anti-IL-1 $\beta, 1: 200$ dilution; anti-NALP3 inflammasome,1:200 dilution; anti-LC-3, 1:400 dilution; anti-LAMP-1, 1:400 dilution; all from Bioss, Boston, MA, USA). The primary antibodies were replaced with phosphate-buffered saline (PBS) in negative controls. After incubation with primary antibodies, the sections were placed in a solution containing a peroxidase-labeled polymer conjugated to a secondary anti-rabbit antibody [EnVision + kit/HRP, Dako, Glostrup, Denmark)] for $30 \mathrm{~min}$ at RT. Positive regions were stained brown with the chromogen 3,3'-diaminobenzidine tetrahydrochloride (DAB, Wako). Following this, sections were counterstained with hematoxylin.

Semiquantitative analysis. A semiquantitative evaluation of the microscopic lesions (numbers of neutrophils and enlarged macrophages with cytoplasmic vacuoles and ASD, alveolar thickening) and immunohistochemical reactions (TNF, IL-1 $\beta$, NALP3 inflammasome) in the lung was conducted in mice treated with Asian sand dust (ASD). Numbers of neutrophils, enlarged macrophages with cytoplasmic vacuoles and ASD particles, and positively immunolabeled cells were counted in 10 microscopic fields at $400 \times$ in mice sacrificed at 24 hours and 2 months after treatment. Alveolar thickening was scored $1=1-3$ cell thickness; $2=4-6$ cell thickness; $3=>7$ cell thickness in 10 microscopic fields at $400 \times$ in mice sacrificed at 1, 2 and 3 months after treatment. This was performed ten times and the mean values were calculated and recorded.

Transmission electron microscopy. Of the mice in each group that was sacrificed 24 hours after treatment, half of the longitudinal sections of each lung lobe were used for transmission electron microscopy. Cubes of 1-2 $\mathrm{mm}^{3}$ were prepared from each section. They were fixed in $2.5 \%$ glutaraldehyde for $3 \mathrm{~h}$ at $4^{\circ} \mathrm{C}$, rinsed in $0.1 \mathrm{M}$ phosphate buffer $(\mathrm{pH}=7.4)$, post fixed for $1 \mathrm{~h}$ in $1 \%$ osmium tetroxide, dehydrated in alcohol, and embedded in epoxy resin. Semi-thin $(1 \mu \mathrm{m})$ sections were stained using $1 \%$ toluidine blue. Ultra-thin sections stained with uranyl acetate and lead citrate were then examined under a Hitachi $\mathrm{H}-500 \mathrm{H}$ electron microscope (Hitachi, Tokyo, Japan).

Statistical analysis. Statistical analysis of semiquantitative histology and immunohistochemistry was performed using a Student's t-test for two-group comparisons. $P$ values less than $1 \%(p<0.01)$ and $5 \%(p<0.05)$ were considered statistically significant in semiquantitative histology and immunohistochemistry, respectively. 


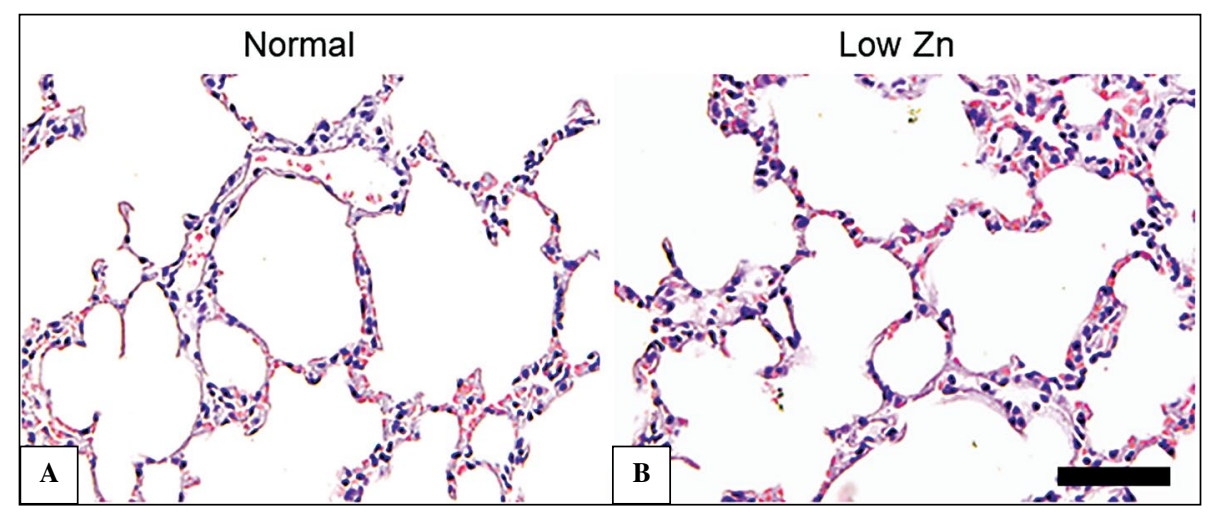

Figure 1. Lung of control mice with normal (A) and low (B) levels of serum Zn, showing no pathological changes. Hematoxylin and eosin $(\mathrm{H} \& \mathrm{E})$ staining. Bar $=100 \mu \mathrm{m}$.

\section{Results}

\section{Morphological changes in lungs of mice with low and normal Zn serum levels that were instilled with $A S D$}

Lungs from control mice with normal and low levels of serum $\mathrm{Zn}$ showed no pathological changes (Fig. 1A, B). Histological examination of lung sections revealed similar patterns in the lesions of mice fed normal- and low-level $\mathrm{Zn}$ diets following treatment with ASD particles (Fig. 2A-J). Interstitial inflammation characterized by neutrophil infiltration and macrophage accumulation was observed throughout the experimental time course; the inflammatory changes were more prominent and persistent in mice fed on a low $\mathrm{Zn} \operatorname{diet}$ (Fig. 2A-J). Neutrophil infiltration was most prominently observed at 24 hours after the treatment (Fig. 3A). Thereafter, thickening of the alveolar wall with an increase in the number of macrophages at the alveolar septa was observed over time; the change was prominent in the low serum $\mathrm{Zn}$ mice (Fig. 2A-J, 3C). Cytoplasmic vacuolar changes of enlarged macrophages containing fine ASD particles were observed in the lesions; the changes were most obvious in mice fed on a low $\mathrm{Zn} \operatorname{diet}$ (Fig. 3B, 8A-D).

\section{The expression of cytokines as well as} inflammasome, autophagic and lysosomal markers The cytoplasm of macrophages in the inflammatory lesions showed positive immunolabeling for TNF (Fig. 4), IL-1 $\beta$ (Fig. 5), and inflammasome marker (NALP3) (Fig. 6) throughout the examined time period. Semi-quantitative analysis revealed a larger number of TNF-positive macrophages in mice with normal level of serum $\mathrm{Zn}$ and a larger number of IL- $1 \beta$-positive macrophages in mice with low level of serum $\mathrm{Zn}$ (Fig. 7). In addition, positive immunolabeling for LC-3 (an autophagy marker) (Fig. 8E-H) and LAMP-1 (a lysosome marker) (Fig. 8I-L) was also displayed in the cytoplasm of macrophages containing fine ASD particles; LC-3 labeling was less prominent in mice with lower serum $\mathrm{Zn}$ concentration(Fig. 8E-H).

\section{Ultrastructural changes in the lungs of mice after 24 hours of ASD installation}

Transmission electron microscopy revealed swollen mitochondria and dilated vacuolar structures containing fine ASD particles in the cytoplasm of alveolar macrophages in mice with low serum level Zn (Fig. 9A); closely attached vacuoles of various dilations were frequently observed (Fig. 9B). These changes were not visible in mice with normal serum level $\mathrm{Zn}$.

\section{Discussion}

Quartz (crystalline silica) is known to generate cytotoxic and genotoxic effects in pneumocytes [30]. Amorphous and crystalline silica $\left(\mathrm{SiO}_{2}\right)$ [31-36], as well as ASD [9, 10,37-40] have been reported to cause inflammatory responses and damage with the release of inflammatory cytokines including IL-6 and TNF and with the generation of reactive oxygen species (ROS) in the lungs of experimental animals. Si was the major inorganic chemical element in the ASD tested in this study, which was derived from quartz and feldspar [28]. A previous report suggested that the concentration of $\mathrm{SiO}_{2}$ contributed to the majority of the inflammatory responses induced by ASD [37]; Si may be responsible for these inflammatory changes.

This study examined pulmonary toxicity induced by intratracheal instillation of a high dose $(3.0 \mathrm{mg})$ of the mineral component of ASD particles, free from chemical and biological substances. A lung histological examination revealed similar patterns in the 


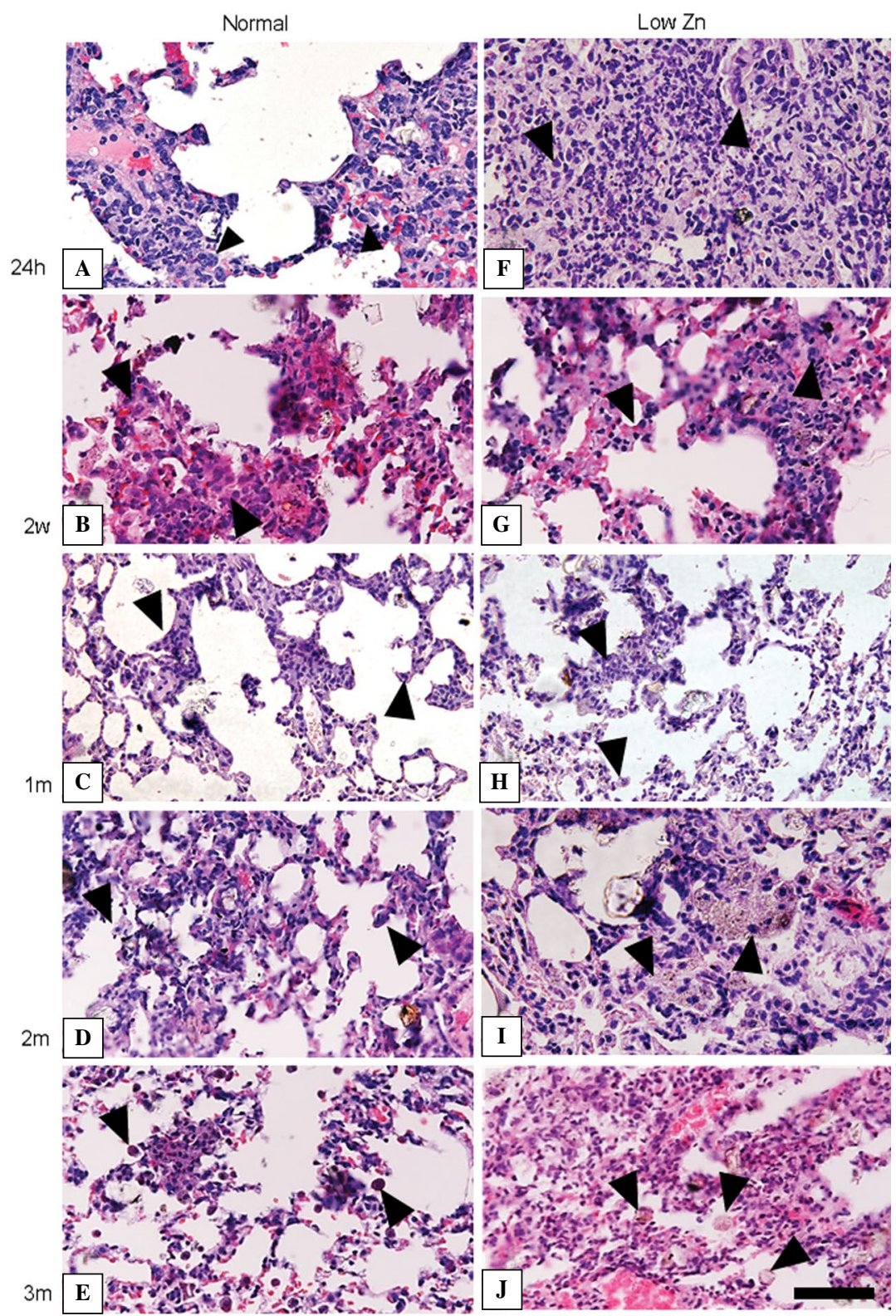

Figure 2. Lung lesions of mice with normal (A-E) and low (F-J) serum zinc concentration mice sampled at 24 hours (A, F), 2 weeks $(\mathbf{B}, \mathbf{G}), 1$ month $(\mathbf{C}, \mathbf{H}), 2$ months $(\mathbf{D}, \mathbf{I})$, and 3 months (E, J) after Asian sand dust (ASD) instillation as described in Methods. Interstitial inflammation characterized by neutrophil infiltration and macrophage accumulation (arrowheads) was observed throughout the experimental time course; the inflammatory changes were more prominent and persistent in mice with a low serum $\mathrm{Zn}$ level (A-J). Neutrophil infiltration dominated at 24 hours after the treatment (A, F). Thereafter, an increase in the number of macrophages at the alveolar septa was observed over time (A-J). H\&E staining. Bar $=100 \mu \mathrm{m}$.

lesions of normal- and low-serum levels of $\mathrm{Zn}$ in mice treated with ASD; these changes were both purulent (acute) and pyogranulomatous (chronic) in nature. These findings are largely in agreement with previous reports of pulmonary toxicity in mice induced by the same dose of intratracheally instilled ASD particles; this is relevant for both the acute purulent inflammation and following chronic granulomatous inflammation [9-12]. However, the inflammatory changes appeared to be more prominent and persistent in mice with low levels of serum $\mathrm{Zn}$. Increased inflammation and organ damage under zinc deficient condition were also reported in a murine polymicrobial sepsis model [41]. Zn was previously reported to influence inflammation by the production and signaling of numerous inflammatory cytokines including TNF and IL- $1 \beta$ in a variety of cell types [23-25, 42]. Immunohistochemistry demonstrated a larger number of 


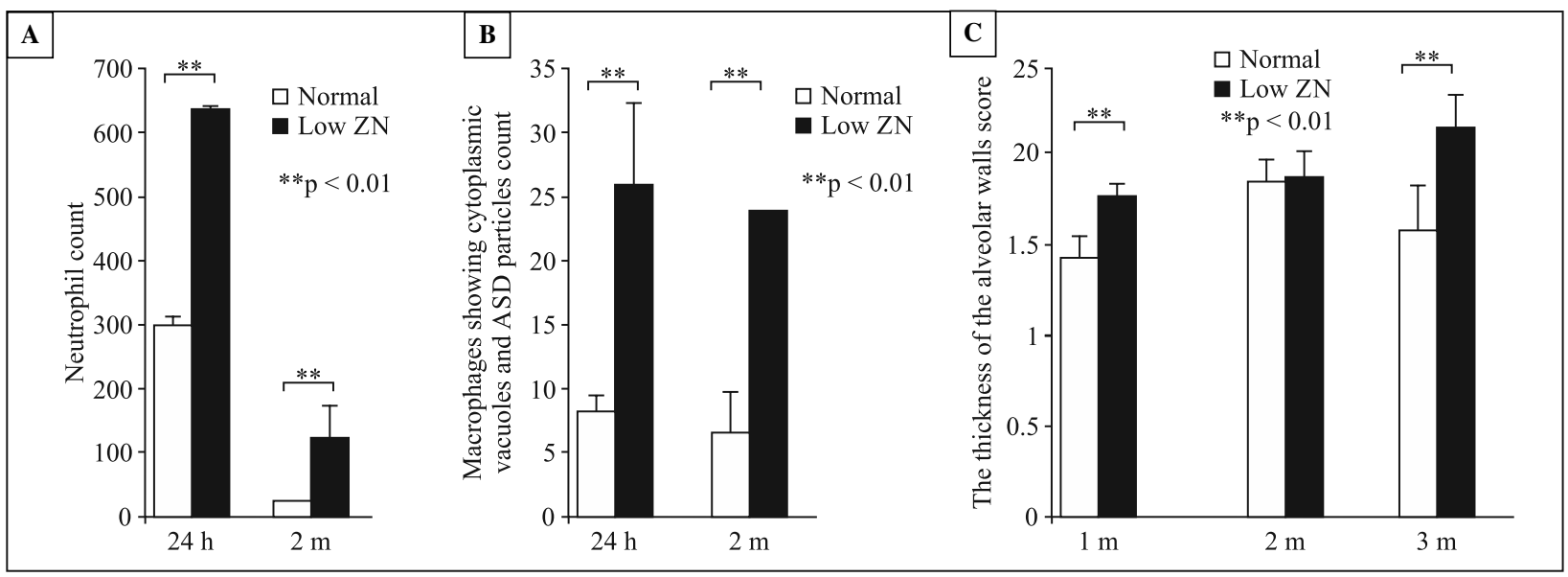

Figure 3. Semiquantitative analysis of the lung lesions in mice with normal (open bars) and low (filled bars) serum zinc levels sacrificed after ASD instillation. A larger number of neutrophils (A) and enlarged macrophages with cytoplasmic vacuoles and ASD particles (B) were observed in mice with low serum Zn sampled at 24 hours and 2 months $(2 \mathrm{~m})$ after treatment with ASD. Thickening of the alveolar wall was also evident in mice with low serum Zn after 1 and 3 months from ASD instillation (C). Abbreviations as in the legend to Figure 2. ${ }^{* *} \mathrm{p}<0.01$.
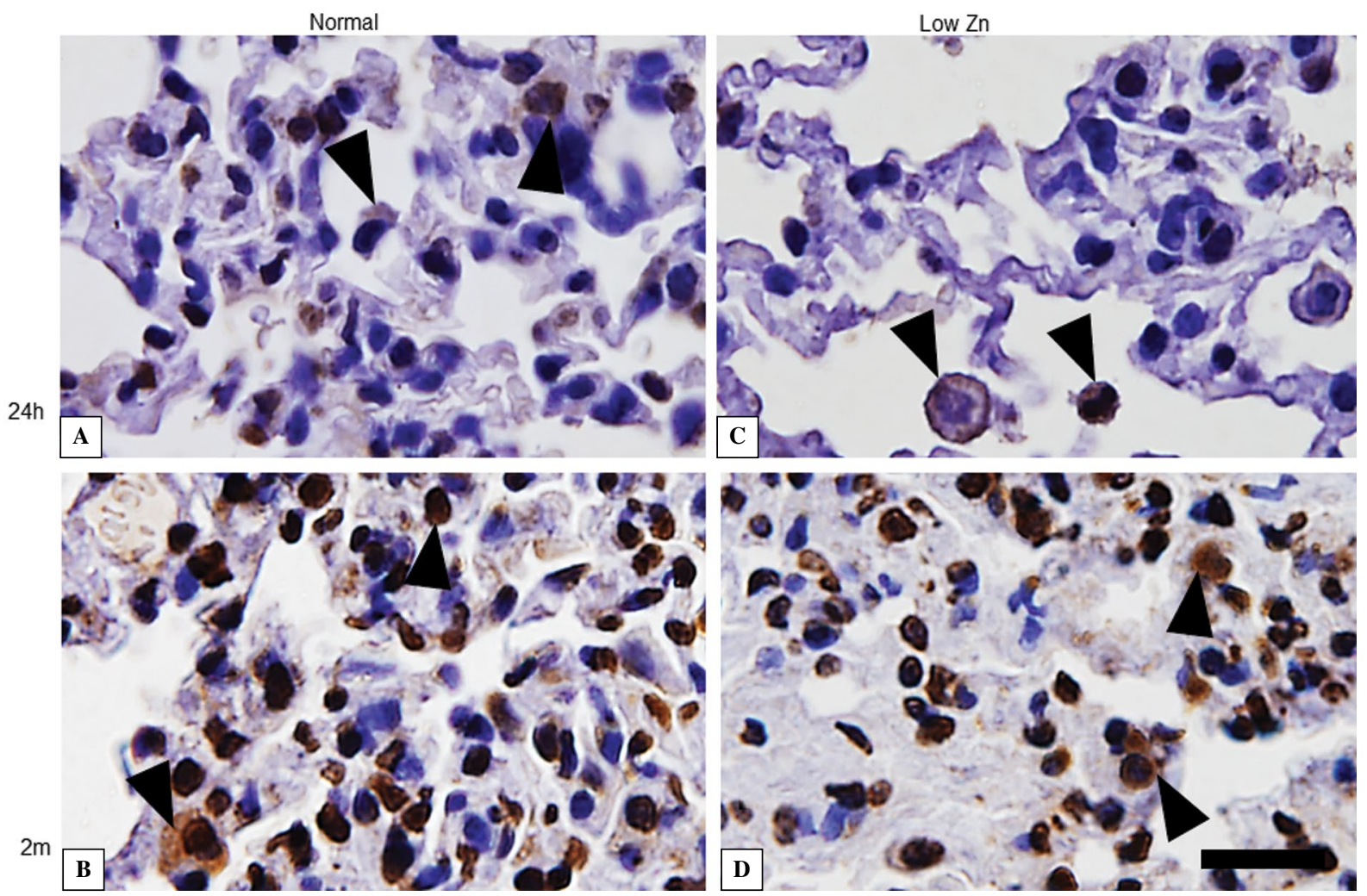

Figure 4. Tumor necrosis factor (TNF) immunohistochemistry in the lung lesions of mice with normal (A, B) and low (C, D) serum zinc levels at 24 hours (A, C) and 2 months (B, D) after ASD instillation. Macrophages (arrowheads) in the inflammatory lesions show positive immunolabeling for TNF. The immunohistochemical staining was performed as described in Methods. Bar $=50 \mu \mathrm{m}$. Abbreviations as in the legend to Figure 2 .

TNF and IL- $1 \beta$-positive macrophages in normal- and low-level serum $\mathrm{Zn}$ mice, respectively, suggesting that a decreased serum $\mathrm{Zn}$ level may induce modulation of cytokine expression, resulting in prolonged purulent inflammation associated with increased IL- $1 \beta$ expression in mice with low levels of serum $\mathrm{Zn}$. 

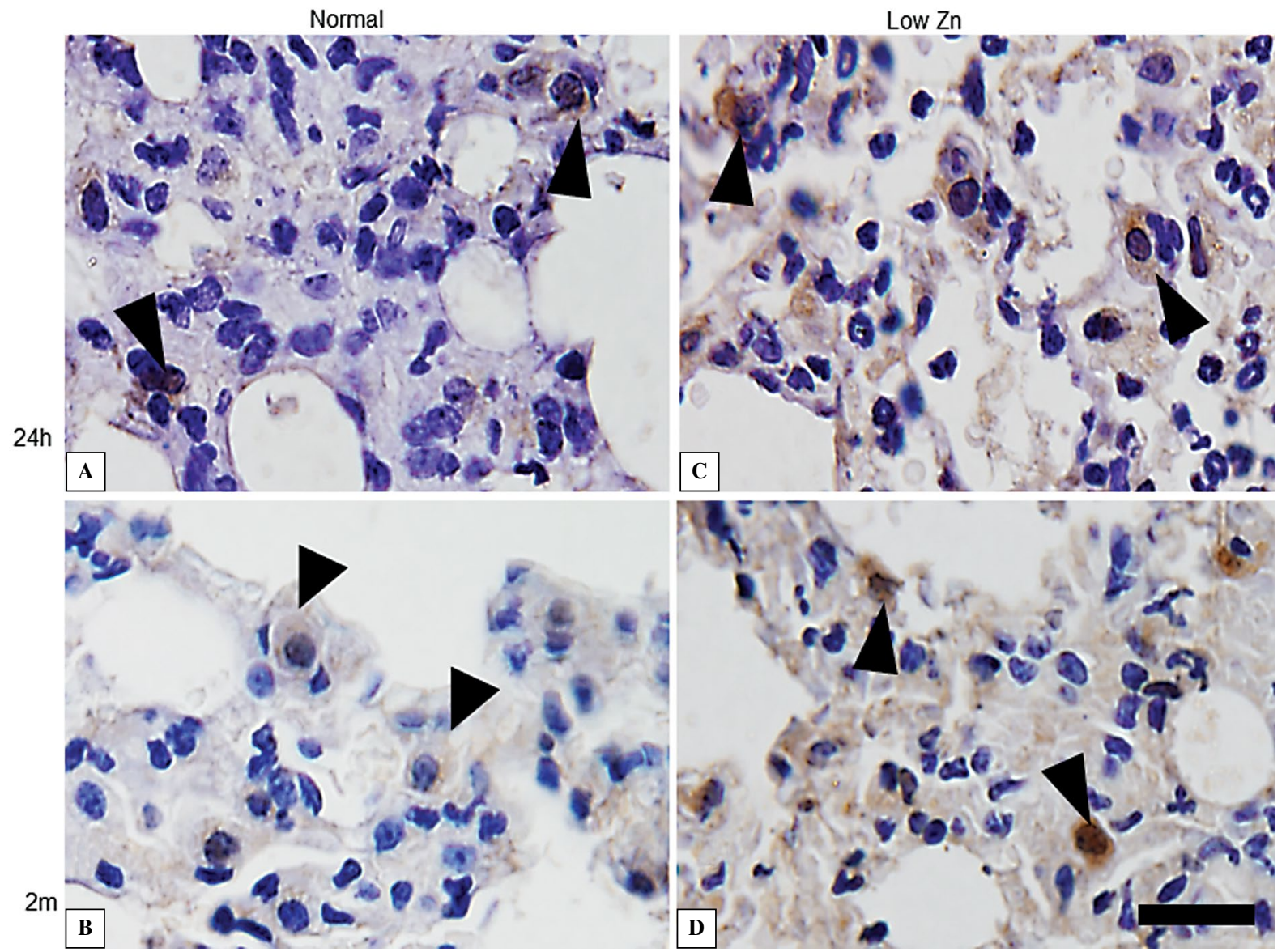

Figure 5. Interleukin (IL)- $1 \beta$ immunohistochemistry in the lung lesions of mice with normal (A, B) and low (C, D) serum zinc levels at 24 hours $(\mathbf{A}, \mathbf{C})$ and 2 months $(\mathbf{B}, \mathbf{D})$ after ASD instillation. Macrophages (arrowheads) in the inflammatory lesions show positive immunolabeling for IL-1 $\beta$. Bar $=50 \mu \mathrm{m}$.

Cytoplasmic vacuolar changes of enlarged macrophages containing fine ASD particles were observed in lung lesions in this study; the changes appeared to be more prominent in mice with low levels of serum $\mathrm{Zn}$. Although the overall appearance of vacuoles appeared similar under light microscopy, cytoplasmic vacuolization may occur by a wide variety of stimuli. The vacuoles in question may be derived from distinct membrane sources including the endosome, lysosome, autolysosome, Golgi apparatus, and endoplasmic reticulum, suggesting that almost all cellular compartments can be dilated and vacuolated [43]. Immunohistochemistry involving LAMP-1 has been previously used to colocalize dilated vacuoles with lysosomes and phagolysosomal complexes [44]. Positive LAMP-1 staining and the presence of sequestrated ASD fine particles in the membranous structure of lung macrophages imply that observed vacuoles were lysosomes and/or autolysosomes. Lysosomes become enlarged (vacuolated) due to the influx of water, resulting from an increase in lysosomal membrane permeability induced by sequestrated particles [43]. Silica has been reported to increase lysosomal membrane permeability with disruption of the normal internalization process leading to cytokine/enzyme release and cell death [14, 45]. Numerous studies have shown that $\mathrm{Zn}$ deficiency alters the composition of the plasma membrane [46]. Decreased $\mathrm{Zn}$ concentration in the erythrocyte membrane is associated with increased osmotic fragility of erythrocytes in rat [47] and pig [48]. This increase in the fragility of the lysosomal membrane, and resultant water influx into the cytoplasm, could be involved in the development of the vacuolar dilation that was frequently observed in the macrophages of lung lesions in mice with low serum $\mathrm{Zn}$ concentration.

Activation of autophagy was demonstrated in the alveolar macrophages of silicosis mouse model [49] and in the cultured alveolar macrophages exposed to silica [50-53] in response to silicon toxicity; autophagy is an important pro-survival mechanism for maintaining metabolic homeostasis under stress [54, 


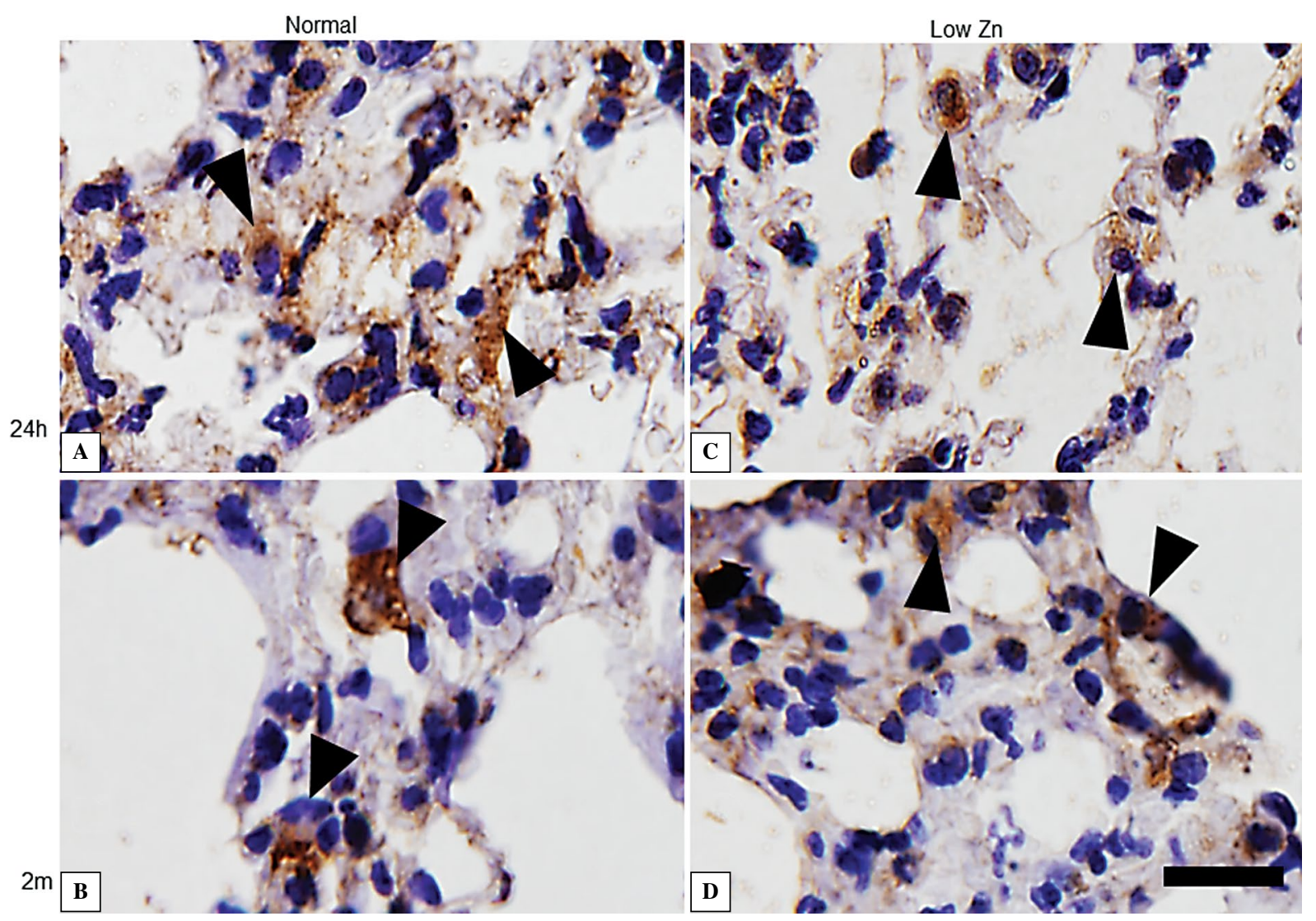

Figure 6. Inflammasome (NALP3) immunohistochemistry in the lung lesions of mice with normal (A, B) and low (C, D) serum zinc levels treated at 24 hours (A, C) and 2 months (B, D) after ASD instillation. Macrophages (arrowheads) in the inflammatory lesions show positive immunolabeling for NALP3. Bar $=50 \mu \mathrm{m}$.

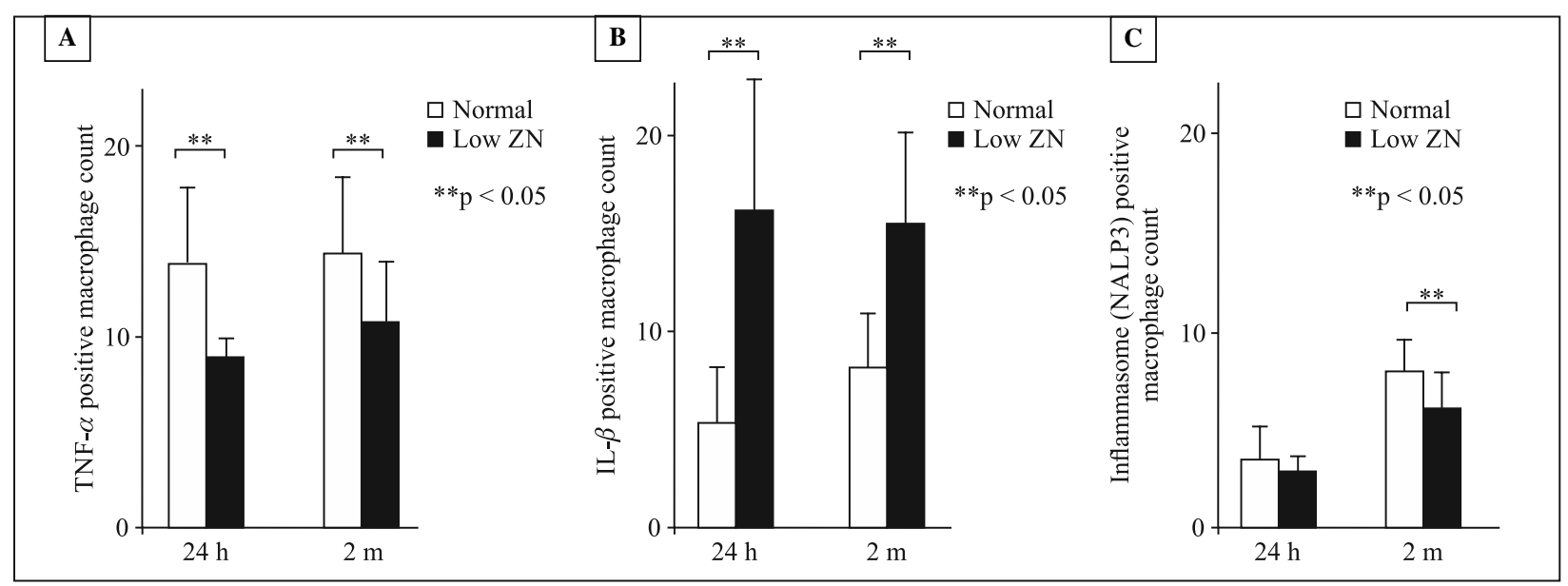

Figure 7. Semiquantitative analysis of the immunorectivity of TNF (A), IL-1 $\beta$ (B) and NALP3 component inflammasome (C) in the lungs of mice with normal (open bars) and low (filled bars) serum zinc levels at 24 hours and 2 months after ASD instillation. A larger number of TNF-positive macrophages in mice with normal serum $\mathrm{Zn}$ level and a larger number of IL-1 $\beta$-positive macrophages in mice with low serum $\mathrm{Zn}$ level were observed. Abbreviations as in the legends to Figure 2 and Figure 3. ${ }^{* *} \mathrm{p}<0.05$. 


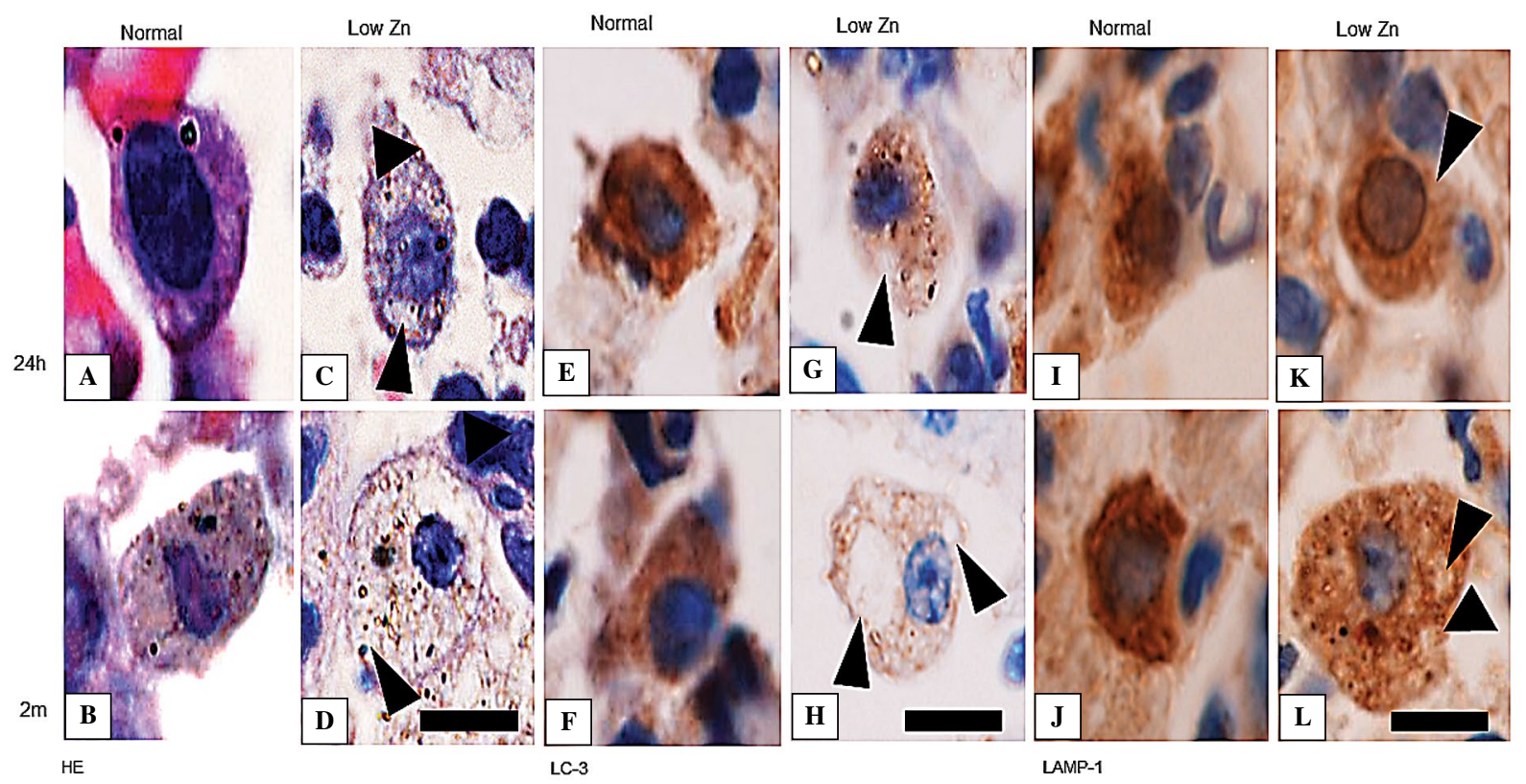

Figure 8. Cytoplasmic vacuolar changes (arrowheads) of enlarged macrophages containing fine particles of Asian sand dust were observed in lung lesions of mice (A-L). The changes were most prominent in mice with low serum zinc level $(\mathbf{C}, \mathbf{D}$, G, H, K, L). Positive immunolabeling for LC-3 (an autophagy marker, E-H) and LAMP-1 (a lysosome marker, I-L) were observed in the cytoplasm of macrophages; LC-3 positive staining was less prominent in mice with low serum zinc level (G, H). Bars $=20 \mu \mathrm{m}$. A-D, H\&E staining; E-H, LC-3 immunohistochemistry; I-L, LAMP-1 immunohistochemistry (I-L).
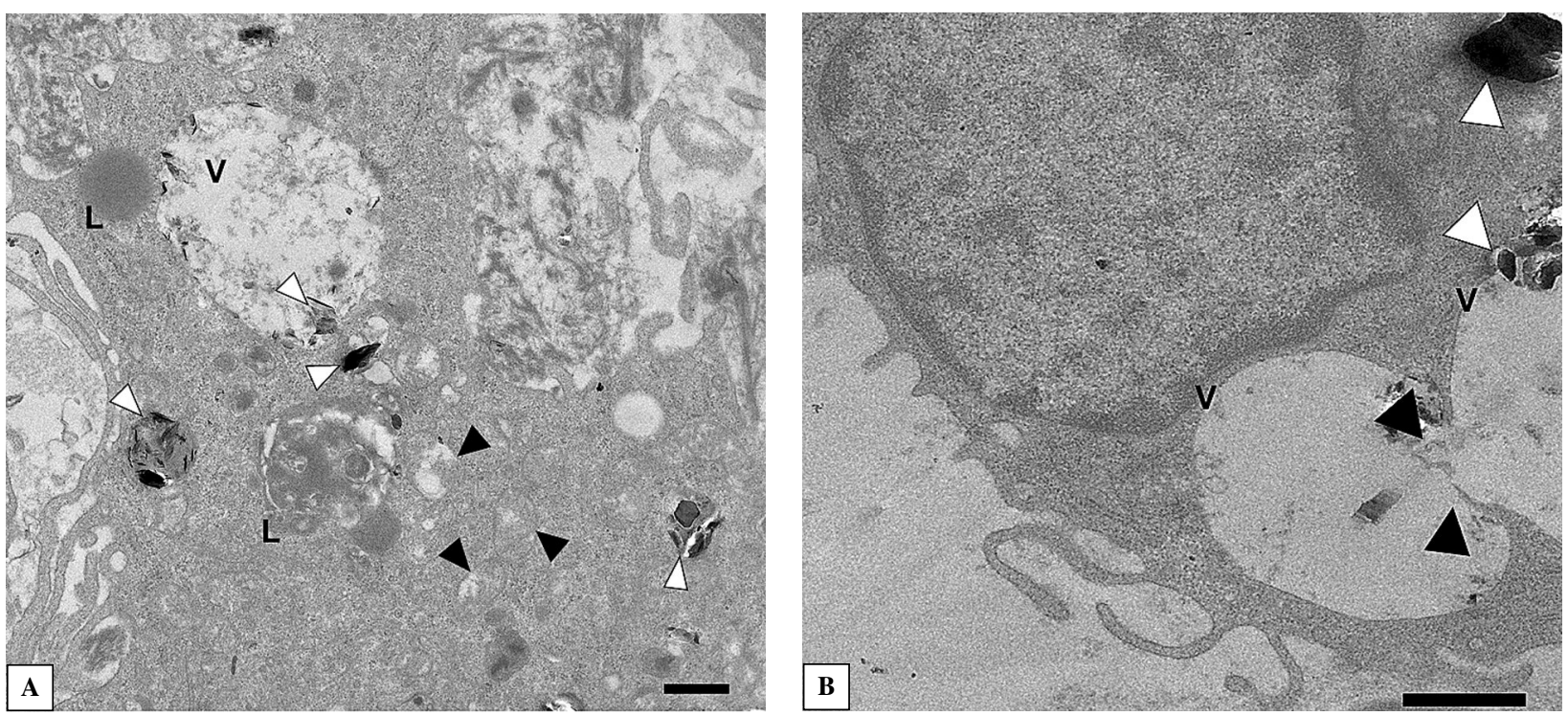

Figure 9. Transmission electron microscopy (TEM) images of the macrophages in the lung lesions of mice with low serum zinc level at 24 hours after ASD instillation. A. Lysosomes (L), swollen mitochondria (black arrowheads) and dilated vacuolar structures (V) containing fine particles (white arrowheads) of ASD are present in the cytoplasm. B. Closely attached dilated vacuoles (V) containing fine particles (white arrowheads) of ASD showing fusion of the membranes (black arrowheads). Tissues were prepared for TEM as described in Methods. Bars $=1 \mu \mathrm{m}$.

55]. Although the mechanisms by which Zn modulates autophagy are yet to be defined, $\mathrm{Zn}$ is reported to be a positive regulator of autophagy; in vitro studies have consistently shown that $\mathrm{Zn}$ is critical for basal and induced autophagy [56]. Positive immunolabeling for LC-3 (an marker of autophagy) and LAMP-1 
(a lysosome marker) was also observed in the cytoplasm of enlarged macrophages containing fine ASD particles; positive LC-3 staining was less prominent in low level serum $\mathrm{Zn}$ mice, suggesting that autophagy was being blocked as a result of $\mathrm{Zn}$ deficiency.

\section{Conclusions}

Results of this study suggest that low serum $\mathrm{Zn}$ concentration may induce the modulation of cytokine expression and lysosomal malfunction by phagocytotic and/or autophagic mechanisms, as well as the resultant interstitial pyogranulomatous inflammation, in the lungs of mice treated with ASD particles.

\section{Acknowledgements}

This study was supported in part by a Grant-in-Aid for Scientific Research (S: No. 25220201, C: No. 16K08034) from JSPS KAKENHI and by Joint Research Program of Arid Land Research Center, Tottori University (No. 28C2018).

\section{References}

1. Yang CY, Tsai SS, Chang CC, et al. Effects of Asian dust storm events on daily admissions for asthma in Taipei, Taiwan. Inhal Toxicol. 2005; 17(14): 817-821, doi: 10.1080/08958370500241254, indexed in Pubmed: 16282159.

2. Bell ML, Levy JK, Lin Z. The effect of sandstorms and air pollution on cause-specific hospital admissions in Taipei, Taiwan. Occup Environ Med. 2008; 65(2): 104-111, doi: 10.1136/ /oem.2006.031500, indexed in Pubmed: 17626134.

3. Chan CC, Chuang KJ, Chen WJ, et al. Increasing cardiopulmonary emergency visits by long-range transported Asian dust storms in Taiwan. Environ Res. 2008; 106(3): 393-400, doi: 10.1016/j.envres.2007.09.006, indexed in Pubmed: 17959168.

4. Cheng MF, Ho SC, Chiu HF, et al. Consequences of exposure to Asian dust storm events on daily pneumonia hospital admissions in Taipei, Taiwan. J Toxicol Environ Health A. 2008; 71(19): 1295-1299, doi: 10.1080/15287390802114808, indexed in Pubmed: 18686199.

5. Chiu HF, Tiao MM, Ho SC, et al. Effects of Asian dust storm events on hospital admissions for chronic obstructive pulmonary disease in Taipei, Taiwan. Inhal Toxicol. 2008; 20(9): 777-781, doi: 10.1080/08958370802005308, indexed in Pubmed: 18645716.

6. Lai LW, Cheng WL. The impact of air quality on respiratory admissions during Asian dust storm periods. Int J Environ Health Res. 2008; 18(6): 429-450, doi: 10.1080/09603120802272227, indexed in Pubmed: 19031147.

7. Kang JH, Liu TC, Keller J, et al. Asian dust storm events are associated with an acute increase in stroke hospitalisation. J Epidemiol Community Health. 2013; 67(2): 125-131, doi: 10.1136/jech-2011-200794, indexed in Pubmed: 22826296.

8. Yang CY, Cheng MH, Chen CC. Effects of Asian dust storm events on hospital admissions for congestive heart failure in Taipei, Taiwan. J Toxicol Environ Health A. 2009; 72(5): 324-328, doi: 10.1080/15287390802529880, indexed in Pubmed: 19184748.

9. Ichinose T, Nishikawa M, Takano H, et al. Pulmonary toxicity induced by intratracheal instillation of Asian yellow dust (Kosa) in mice. Environ Toxicol Pharmacol. 2005; 20(1):
48-56, doi: 10.1016/j.etap.2004.10.009, indexed in Pubmed: 21783567.

10. Naota M, Mukaiyama T, Shimada A, et al. Pathological study of acute pulmonary toxicity induced by intratracheally instilled Asian sand dust (kosa). Toxicol Pathol. 2010; 38(7): 1099-1110, doi: 10.1177/0192623310385143, indexed in Pubmed: 20884819.

11. Naota M, Shiotsu S, Shimada A, et al. Pathological study of chronic pulmonary toxicity induced by intratracheally instilled Asian sand dust (kosa). Toxicol Pathol. 2013; 41(1): 48-62, doi: 10.1177/0192623312452490, indexed in Pubmed: 22744225 .

12. Shimada A, Kohara Y, Naota M, et al. Pathological study of chronic pulmonary toxicity induced by intratracheally instilled Asian sand dust (Kosa): possible association of fibrosis with the development of granulomatous lesions. Folia Histochem Cytobiol. 2015; 53(4): 294-306, doi: 10.5603/fhc.a2015.0030, indexed in Pubmed: 26615817.

13. Beamer CA, Migliaccio CT, Jessop F, et al. Innate immune processes are sufficient for driving silicosis in mice. J Leukoc Biol. 2010; 88(3): 547-557, doi: 10.1189/jlb.0210108, indexed in Pubmed: 20576854.

14. Hamilton RF, Thakur SA, Holian A. Silica binding and toxicity in alveolar macrophages. Free Radic Biol Med. 2008; 44(7): 1246-1258, doi: 10.1016/j.freeradbiomed.2007.12.027, indexed in Pubmed: 18226603.

15. Hirota JA, Hirota SA, Warner SM, et al. The airway epithelium nucleotide-binding domain and leucine-rich repeat protein 3 inflammasome is activated by urban particulate matter. J Allergy Clin Immunol. 2012; 129(4): 1116-25.e6, doi: 10.1016/j.jaci.2011.11.033, indexed in Pubmed: 22227418.

16. Hosseinian N, Cho Y, Lockey RF, et al. The role of the NLRP3 inflammasome in pulmonary diseases. Ther Adv Respir Dis. 2015; 9(4): 188-197, doi: 10.1177/1753465815586335, indexed in Pubmed: 26012351.

17. Yazdi AS, Guarda G, Riteau N, et al. Nanoparticles activate the NLR pyrin domain containing 3 (Nlrp3) inflammasome and cause pulmonary inflammation through release of IL-1 $\beta$ and IL-1 $\beta$. Proc Natl Acad Sci U S A. 2010; 107(45): 19449-19454, doi: 10.1073/pnas.1008155107, indexed in Pubmed: 20974980.

18. Vallee BL, Falchuk KH. The biochemical basis of zinc physiology. Physiol Rev. 1993; 73(1): 79-118, doi: 10.1152/physrev.1993.73.1.79, indexed in Pubmed: 8419966.

19. Cai C, Lin P, Zhu H, et al. Zinc Binding to MG53 Protein Facilitates Repair of Injury to Cell Membranes. J Biol Chem. 2015; 290(22): 13830-13839, doi: 10.1074/jbc.M114.620690, indexed in Pubmed: 25869134.

20. McNeil PL, Kirchhausen T. An emergency response team for membrane repair. Nat Rev Mol Cell Biol. 2005; 6(6): 499-505, doi: 10.1038/nrm1665, indexed in Pubmed: 15928713.

21. Kamei S, Fujikawa H, Nohara H, et al. Zinc Deficiency via a Splice Switch in Zinc Importer ZIP2/SLC39A2 Causes Cystic Fibrosis-Associated MUC5AC Hypersecretion in Airway Epithelial Cells. EBioMedicine. 2018; 27: 304-316, doi: 10.1016/j. ebiom.2017.12.025, indexed in Pubmed: 29289532.

22. Zhou X, Fragala MS, McElhaney JE, et al. Conceptual and methodological issues relevant to cytokine and inflammatory marker measurements in clinical research. Curr Opin Clin Nutr Metab Care. 2010; 13(5): 541-547, doi: 10.1097/ /MCO.0b013e32833cf3bc, indexed in Pubmed: 20657280.

23. Bao S, Liu MJ, Lee B, et al. Zinc modulates the innate immune response in vivo to polymicrobial sepsis through regulation of NF-kappaB. Am J Physiol Lung Cell Mol Physiol. 2010; 298(6): L744-L754, doi: 10.1152/ajplung.00368.2009, indexed in Pubmed: 20207754.

24. Bao B, Prasad AS, Beck FWJ, et al. Zinc supplementation decreases oxidative stress, incidence of infection, and generation 
of inflammatory cytokines in sickle cell disease patients. Transl Res. 2008; 152(2): 67-80, doi: 10.1016/j.trsl.2008.06.001, indexed in Pubmed: 18674741.

25. Prasad AS, Beck FWJ, Bao B, et al. Zinc supplementation decreases incidence of infections in the elderly: effect of zinc on generation of cytokines and oxidative stress. Am J Clin Nutr. 2007; 85(3): 837-844, indexed in Pubmed: 17344507.

26. Blumberg J. Nutritional needs of seniors. J Am Coll Nutr. 1997; 16(6): 517-523, indexed in Pubmed: 9430078.

27. Hambidge KM, Krebs NF. Zinc deficiency: a special challenge. J Nutr. 2007; 137(4): 1101-1105, indexed in Pubmed: 17374687.

28. Nishikawa M, Quan H, Morita M. Preparation and evaluation of certified reference materials for Asian mineral dust. Global Environ Res. 2000; 1: 103-113.

29. Iwatsuki M, Kyotani T, Katsubar K. Fractional determination of elemental carbon and total soluble and insoluble organic compounds in airborne particulate matter by thermal analysis combined wirh extraction and heavy liquid separation. Bunseki Kagaku 1998; 43: 879-884, doi: 10.2116/analsci. 14.321.

30. Schins RPF, Duffin R, Höhr D, et al. Surface modification of quartz inhibits toxicity, particle uptake, and oxidative DNA damage in human lung epithelial cells. Chem Res Toxicol. 2002; 15(9): 1166-1173, indexed in Pubmed: 12230410.

31. Murphy SA, BéruBé KA, Pooley FD, et al. The response of lung epithelium to well characterised fine particles. Life Sci. 1998; 62(19): 1789-1799, indexed in Pubmed: 9585110.

32. Blackford JA, Antonini JM, Castranova V, et al. Intratracheal instillation of silica up-regulates inducible nitric oxide synthase gene expression and increases nitric oxide production in alveolar macrophages and neutrophils. Am J Respir Cell Mol Biol. 1994; 11(4): 426-431, doi: 10.1165/ajrcmb.11.4.7522485, indexed in Pubmed: 7522485.

33. Castranova V, Porter D, Millecchia L, et al. Effect of inhaled crystalline silica in a rat model: time course of pulmonary reactions. Mol Cell Biochem. 2002; 234-235(1-2): 177-184, indexed in Pubmed: 12162431.

34. Huffman LJ, Judy DJ, Castranova V. Regulation of nitric oxide production by rat alveolar macrophages in response to silica exposure. J Toxicol Environ Health A. 1998; 53(1): 29-46, indexed in Pubmed: 9447227.

35. Porter DW, Millecchia LL, Willard P, et al. Nitric oxide and reactive oxygen species production causes progressive damage in rats after cessation of silica inhalation. Toxicol Sci. 2006; 90(1): 188-197, doi: 10.1093/toxsci/kfj075, indexed in Pubmed: 16339787.

36. Rimal B, Greenberg AK, Rom WN. Basic pathogenetic mechanisms in silicosis: current understanding. Curr Opin Pulm Med. 2005; 11(2): 169-173, indexed in Pubmed: 15699791.

37. Ichinose T, Yoshida S, Sadakane K, et al. Effects of asian sand dust, Arizona sand dust, amorphous silica and aluminum oxide on allergic inflammation in the murine lung. Inhal Toxicol. 2008; 20(7): 685-694, doi: 10.1080/08958370801935133, indexed in Pubmed: 18464056.

38. Ichinose T, Yoshida S, Hiyoshi K, et al. The effects of microbial materials adhered to Asian sand dust on allergic lung inflammation. Arch Environ Contam Toxicol. 2008; 55(3): 348-357, doi: 10.1007/s00244-007-9128-8, indexed in Pubmed: 18227959

39. Lei YC, Chan CC, Wang PY, et al. Effects of Asian dust event particles on inflammation markers in peripheral blood and bronchoalveolar lavage in pulmonary hypertensive rats. Environ Res. 2004; 95(1): 71-76, doi: 10.1016/S00139351(03)00136-1, indexed in Pubmed: 15068932.

40. Yanagisawa $\mathrm{R}$, Takano $\mathrm{H}$, Ichinose $\mathrm{T}$, et al. Gene expression analysis of murine lungs following pulmonary exposure to Asian sand dust particles. Exp Biol Med (Maywood). 2007;
232(8): 1109-1118, doi: 10.3181/0612-RM-311, indexed in Pubmed: 17720957.

41. Knoell DL, Julian MW, Bao S, et al. Zinc deficiency increases organ damage and mortality in a murine model of polymicrobial sepsis. Crit Care Med. 2009; 37(4): 1380-1388, doi: 10.1097/CCM.0b013e31819cefe4, indexed in Pubmed: 19242332.

42. Zhou X, Fragala MS, McElhaney JE, et al. Conceptual and methodological issues relevant to cytokine and inflammatory marker measurements in clinical research. Curr Opin Clin Nutr Metab Care. 2010; 13(5): 541-547, doi: 10.1097/ /MCO.0b013e32833cf3bc, indexed in Pubmed: 20657280.

43. Aki T, Nara A, Uemura K. Cytoplasmic vacuolization during exposure to drugs and other substances. Cell Biol Toxicol. 2012; 28(3): 125-131, doi: 10.1007/s10565-012-9212-3, indexed in Pubmed: 22431173.

44. Chen PM, Gombart ZJ, Chen JW. Chloroquine treatment of ARPE-19 cells leads to lysosome dilation and intracellular lipid accumulation: possible implications of lysosomal dysfunction in macular degeneration. Cell Biosci. 2011; 1(1): 10, doi: 10.1186/2045-3701-1-10, indexed in Pubmed: 21711726.

45. Allison AC, Harington JS, Birbeck M. An examination of the cytotoxic effects of silica on macrophages. J Exp Med. 1966; 124(2): 141-154, indexed in Pubmed: 4288309.

46. O'Dell BL. Role of zinc in plasma membrane function. J Nutr. 2000; 130(5S Suppl): 1432S-6S, indexed in Pubmed: 10801956.

47. O’Dell BL, Browning JD, Reeves PG. Zinc deficiency increases the osmotic fragility of rat erythrocytes. J Nutr. 1987; 117(11): 1883-1889, indexed in Pubmed: 3681479.

48. Johanning GL, Browning JD, Bobilya DJ, et al. Effect of zinc deficiency on enzyme activities in rat and pig erythrocyte membranes. Proc Soc Exp Biol Med. 1990; 195(2): 224-229, indexed in Pubmed: 2172996.

49. Shimizu Y, Dobashi K, Nagase H, et al. Co-localization of iron binding on silica with p62/sequestosome1 (SQSTM1) in lung granulomas of mice with acute silicosis. J Clin Biochem Nutr. 2015; 56(1): 74-83, doi: 10.3164/jcbn.14-44, indexed in Pubmed: 25834305.

50. Chen S, Yuan J, Yao S, et al. Lipopolysaccharides may aggravate apoptosis through accumulation of autophagosomes in alveolar macrophages of human silicosis. Autophagy. 2015; 11(12): 2346-2357, doi: 10.1080/15548627.2015.1109765, indexed in Pubmed: 26553601.

51. Guo C, Yang M, Jing Li, et al. Amorphous silica nanoparticles trigger vascular endothelial cell injury through apoptosis and autophagy via reactive oxygen species-mediated MAPK/ $/ \mathrm{Bcl}-2$ and $\mathrm{PI} 3 \mathrm{~K} / \mathrm{Akt} / \mathrm{mTOR}$ signaling. Int $\mathrm{J}$ Nanomedicine. 2016; 11: 5257-5276, doi: 10.2147/IJN.S112030, indexed in Pubmed: 27785026.

52. Liu G, Bi Y, Wang R, et al. Self-eating and self-defense: autophagy controls innate immunity and adaptive immunity. J Leukoc Biol. 2013; 93(4): 511-519, doi: 10.1189/jlb.0812389, indexed in Pubmed: 23271703.

53. Marquardt C, Fritsch-Decker S, Al-Rawi M, et al. Autophagy induced by silica nanoparticles protects RAW264.7 macrophages from cell death. Toxicology. 2017; 379: 40-47, doi: 10.1016/j.tox.2017.01.019, indexed in Pubmed: 28161448 ,

54. Liu G, Bi Y, Wang R, et al. Self-eating and self-defense: autophagy controls innate immunity and adaptive immunity. J Leukoc Biol. 2013; 93(4): 511-519, doi: 10.1189/jlb.0812389, indexed in Pubmed: 23271703.

55. Martínez-Borra J, López-Larrea C. Autophagy and self-defense. Adv Exp Med Biol. 2012; 738: 169-184, doi: 10.1007/978-1-4614-1680-7_11, indexed in Pubmed: 22399380.

56. Hung HH, Huang WP, Pan CY. Dopamine- and zinc-induced autophagosome formation facilitates PC12 cell survival. Cell Biol Toxicol. 2013; 29(6): 415-429, doi: 10.1007/s10565-013-9261-2, indexed in Pubmed: 24077806. 